\section{द्व:}

Entrepreneurial Business and Economics Review

2014, Vol. 2, No. 4

\title{
Analysis of Large-Scale Privatisation in the Czech Republic in the Years 1991-2005 on the Sample of Selected Privatised Companies
}

\author{
Karel Havlíček, Ivana Turková, Gabriela Dlasková
}

\begin{abstract}
A B S T R A C T
Objective: The objective of this paper is to analyse, evaluate and compare the individual methods of Czechoslovak and Czech privatisation in the years 1991-2005 based on long-term economic indicators.

Research Design \& Methods: The empirical research focuses on a sample of 60 companies privatised between 1991 and 2005 which were selected from the list of 3500 large-scale privatised firms in the Czech Republic by the National Property Fund of the Czech Republic and divided into three groups.
\end{abstract}

Findings: The expenditures associated with the large-scale privatisation were covered by the revenues from the sales of property. Based on data analyses, it may be inferred that the best results have been reported by companies sold directly to foreign investors, while lower for voucher privatisation and direct sales to specific domestic investors.

Implications \& Recommendations: The privatisation processes aimed at selecting such owners that would have the capacity required to timely complete the subsequent restructuring process and to set up such procedures that would secure continued operation of the enterprises. The revenues from the sold property is a secondary criterion subordinated to the primary objective.

Contribution \& Value Added: The originality of this work lies in studying the main steps undertaken as part of the so-called large-scale privatisation, after nearly a quarter of a century, and its measurable impacts on the domestic economic environment

\begin{tabular}{llll}
\hline Article type: & research paper \\
& Czech Republic, large-scale privatisation; small-scale privatisation; \\
Keywords: & restitutions; voucher privatisation; direct sales \\
JEL codes: & L33, P21 & & \\
\hline \multicolumn{2}{c}{ Received: 20 July 2014 } & Revised: 15 November 2014 & Accepted: 2 December 2014 \\
\hline
\end{tabular}

\section{Suggested citation:}

Havlíček, K., Turková, I., \& Dlasková, G. (2014). Analysis of Large-Scale Privatisation in the Czech Republic in the Years 1991-2005 on the Sample of Selected Privatised Companies. Entrepreneurial Business and Economics Review, 2(4), 51-70, DOI: http://dx.doi.org/10.15678/EBER.2014.020404. 


\section{INTRODUCTION}

Large-scale privatisation in Czechoslovakia (in the years 1991-1992) and later in the Czech Republic (since 1 January 1993) has long been a highly discussed theme. Since it involved a transfer of all important property in a short period of time from the state to new owners, unique in terms of speed and mode, privatisation has long been a target of political and ideological conflicts. The authors of the text attempt to map, evaluate and compare privatisation methods, not based on their immediate economic effect, but throughout more than 20 years.

In 1989, Czechoslovakia had one of the smallest private sectors of all the postcommunist countries, with the private sector accounting for only about $1.2 \%$ of the overall labour force and producing a minimal part of the national income. Private enterprises were, however, unlike other socialist economies, in relatively good financial condition. At the beginning of the 1990s in Czechoslovakia $73 \%$ of industrial firms were profitable (Pohl et al., 1997). The underlying goal of the privatisation process was to remove the State from the ownership relations of enterprises and, by inference, from all decision-making and control processes (Kočenda \& Lízal, 2003). The necessary economic transformation gave rise to a new pattern of ownership relations, market competition and a newly evolving social stratum of entrepreneurs. This concerned the transformation of the originally socialist centrally planned economy into a capitalist model. The transformation consisted in restructuring the overall system as such, its mutual internal relations and creating new institutions intended to provide efficient performance of the economy.

The Czechoslovak and later Czech privatisation was a historically new operation. Undoubtedly, the whole process involved a variety of unconventional methods of tackling the need to privatise the majority of state property within the shortest possible amount of time, and, still more importantly, without the sufficient capital input.

The objective of the article is to map privatisation paths and its results based on the following economic variables: (i) a number of created jobs, (ii) generated added value and (iii) revenues from income taxes of privatised companies. Quantitative indicators have shifted from the year of privatisation of specific selected companies to the present. Based on the obtained data, another objective was to compare and evaluate particular privatisation methods: direct sales to foreign investors, voucher privatisation, direct sales to domestic investors.

\section{LITERATURE REVIEW}

"Privatisation consists in one entity, which does not know the actual owner or value of the property, selling something to another entity, which is known not to have any capital" (Kouba et al., 2005, p. 56). This perception of privatisation by J. Lewandowski, a Polish economist, is most fitting in the way it captures the actual initial situation in transition economies. Admittedly, all post-communist countries faced this particular issue. Yet, each of the transition countries headed into the privatisation process under a different set of initial conditions and, therefore, opted for various combinations of privatisation forms (Kouba et al., 2005). 
Privatisation, which involves the transfer of public property to private ownership in regions of post-communist countries, has been the focus and research domain of many economists and academic institutions. The Czech privatisation path has not only become a model for many transforming economies, but it has become a basis for modern instruction methods as well (Klaus et al., 2006). However, it has become a target of criticism from many Czech and international economists (Mládek, 1994; Švejnar, 1997). Examples of Czech privatisation are described both in a positive and negative light in publications worldwide. Most of the praise of it focuses on the speed of the overall transformation and, to a certain extent, on the new way of transferring property rights, particularly the voucher privatisation (Katolay \& Hunya, 2000) programme ${ }^{1}$. However, the Czech privatisation has been criticised for its lack of legal preparedness. For many years, the academic community has examined different ways to transfer state property rights effectively. An often discussed potential approach is gradual implementation of a fully functional legal environment prior to the gradual transfer of property rights to specific owners. Part of the academia argues that this can help avoid non-transparent transfers and prevent the formation of non-transparent ownership structures of the privatisation funds into which a large amount of privatised property is allocated. The British path carried out by Margaret Thatcher's government is most often highlighted (McAllister \& Studlar, 1989). However, supporters (Klaus et al., 2006; Tř́ska, 2002; Ježek, 2006) of Czechoslovak and later Czech privatisation paths argue that the legal environment was fully functional and that the method fully corresponded to the laws at the time. Waiting for a supposedly better privatisation environment or following the British path would, according to the supporters of Czech privatisation, prolong the entire privatisation process by 10 years. According to this group of economists (Klaus et al., 2006; Tríska, 2002; Ježek, 2006), the state neither had financial accumen, nor knowledge, nor human resources for their administration and management, and there was a risk of unprecedented corruption. Supporters of fast privatisation point out that all economic and legal steps were carried out in the environment of a fragile democracy, when there was a general demand for the immediate transfer of property. Reasons for emphasising speed included the need to come to terms definitively with the Communist past and concerns about the potential reverse trend of the country transformation to the situation before the Velvet Revolution of 1989. The new economic approach involving Czechoslovak privatisation can be attributed to individuals including Václav Klaus, Tomáš Ježek and Dušan Tříska from the Prague University of Economics.

Research of the transformation of Czechoslovak, as well as the Hungarian economy, has been published by a team of researchers led by Libor Žídek $(2004 ; 2006)$ from Masaryk University in Brno, whose publications and research findings were used as the source material for this article. Critics of the Czechoslovak privatisation methods include leading Czech economist Jan Mládek (1994) and Jan Švejnar (1997) from the Columbia University in New York. The viewpoints of both opposing economists are

\footnotetext{
${ }^{1}$ Voucher privatisation is a privatisation method, under which the citizens were provided with an opportunity to purchase voucher books, at a low cost, with a certain number of vouchers (coupons), which they could redeem for interests in any state-owned companies released for the voucher privatisation by public authorities.
} 
included in the article. A fundamental problem of the elite Czech economists was their political involvement and low level of economic objectivity. Practically all major Czech economists have gradually become leading politicians, and their arguments in favour of or against privatisation methods have been strongly influenced by their political interests and ambitions. For these reasons, the authors had used also totally independent international sources. One of the aims of the authors of this article was to describe and evaluate independently and, to a maximum extent, objectively the results of the privatisation based on clear economic variables.

\section{MATERIAL AND METHODS}

The analysis was carried out in two phases. The first step includes the analysis of general population of privatised companies ( $N=16331$ as indicated in Figure 1 ) and the second step includes the selected sample of privatised companies $(n=60)$. At first the general analysis of the privatisation processes in the Czech Republic was performed for the years 1990-1995 and based on the publicly available data from the Ministry of Finance (Ministerstvo finance, MF ČR) as well as the Ministry of Privatisation (Ministerstvo pro správu národního majetku a jeho privatizaci, existing in the years 1993-1996) and the National Property Fund of the Czech Republic (Fond národního majetku České republiky, FNM ČR, existing in the years 1991-2005). Secondly, the in-depth analysis was performed on a sample of selected privatised enterprises to evaluate the results of privatisation.

For the purposes of the present analysis, we considered 2005 as the official final year of the privatisation process (Annual Report 2005. National Property Fund, 2005). We decided to explore the effects and parameters set under a group of selected enterprises privatised under the large-scale privatisation. The analysis consisted of quantitative empirical research based on primary data. The general population of all privatised units in the Czech Republic in the years 1991-2005 amounted to 16331 (Figure 1). The enterprises (the sample research) were picked out of the list of units privatised by the National Property Fund of the Czech Republic. Out of approximately 3500 large-scale privatized units, we picked 60 enterprises from the industrial sector. The main criterion for inclusion and selection of the enterprises to be examined was staff count exceeding 250 at the time of the privatisation. The sample pool consists of only companies that survived. The aim was not to evaluate the proportion of survivors and bankrupt enterprises, but to analyse and compare the economic effectiveness of operating privatized companies.

These 60 selected major enterprises privatised between 1991 and 2005 were divided into three groups equally $(3 \times 20)$ according to the privatisation method employed. The groups were created with an account taken of the importance of the specific methods: enterprises privatised (i) via direct sales to foreign investors; (ii) under voucher privatisation; (iii) via direct sales to domestic investors.

The results of the privatisation process were evaluated on the sample of selected Czech privatised enterprises $(n=60)$ and were assessed by taking into account the following three factors:

i. The overall public income tax revenue for all the units within the group, starting from the end of privatisation and during the entire existence of the privatised business units or their successors; 
ii. Average annual number of direct jobs created by the group of enterprises under consideration, namely starting from the end of privatisation and during the entire existence of the privatised business units or their successors;

iii. Value added per employee generated on an annual basis.

The objective of this paper is to analyse, evaluate and compare the individual methods of Czechoslovak and Czech privatisation in the years 1991-2005 based on long-term economic indicators.

\section{RESULTS AND DISCUSSION}

\section{Analysis of Privatisation Processes in the Czech Republic}

The privatisation process in the Czech Republic was carried out under three programs (Kočenda \& Valachy, 2001):

- restitution started in 1990 and finished in 1991,

- small-scale privatisation introduced in 1990, started and 1991 and officially terminated in 1993,

- large-scale (or mass) privatisation started in 1991 and formally concluded in 1995.

The privatisation process in the Czech Republic, apart from the three above mentioned programmes, still continued after 1995, nevertheless its intensity was lower. The year 1999 may be regarded from the practical point of view as the closing year of the real privatisation process in terms of the decreasing number of projects assigned, although the year 2005 is perceived officially as the end of the privatisation processes in the Czech Republic. The decreasing trend in the number of privatised units is shown in Figure 1.

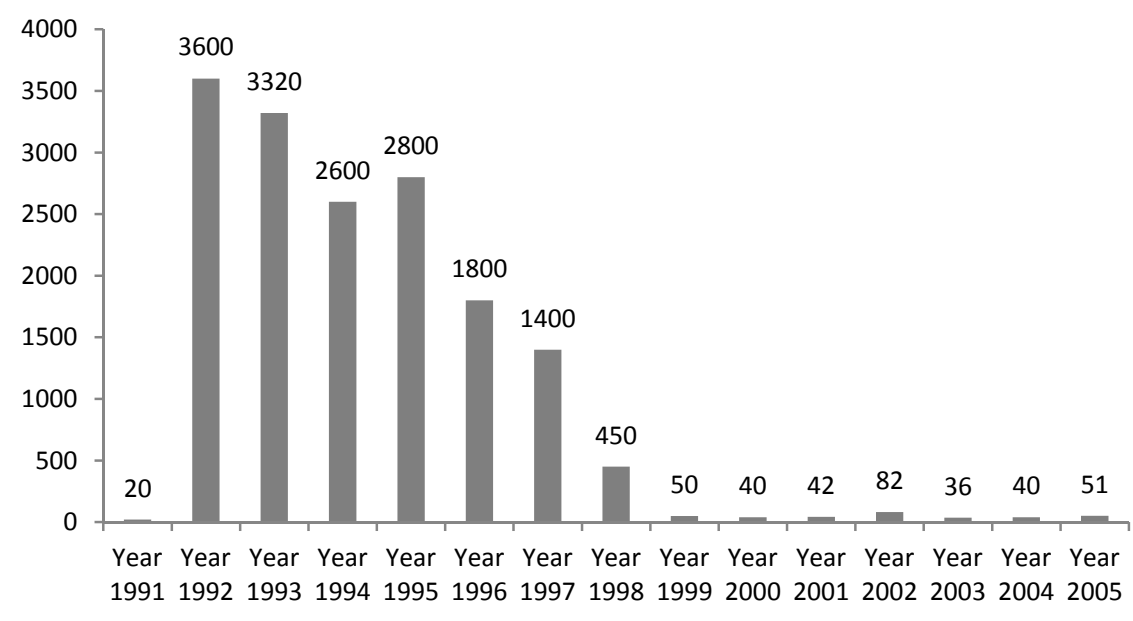

Figure 1. Number of privatised units in the Czech Republic in the years 1991-2005 Source: own elaboration based on National Property Fund (2005).

Two basic methods of approaching privatisation were considered at the beginning of economic transformation in 1991 (Ježek, 2006). The first consisted of converting stateowned enterprises into joint-stock companies, which would initially remain in the hands 
of the state, which was expected to restructure the enterprises before selecting an appropriate new owner. The other scenario assumed the enterprises would be privatised immediately and restructured afterwards, under the control and at full expense and risk of the new owner. With the critical criterion and the clear-cut objective being to complete the privatisation project within a short period of time, the former scenario was opted for, i.e. rapid transfer to the selected owners. The overall property rights transfer strategy had speed as its fundamental criterion and involved selecting such owners that would have, if not demonstrable, then at least the minimum capacity required to complete the subsequent restructuring process and to set up procedures that would secure continued operation of the enterprises. The receipts from the sold property rights were a secondary criterion (Tríska, 2002).

The first phase of the privatisation process aimed at establishing a market order, which would create conditions for a higher efficiency of the enterprises. In order for such a market order to be set up, it was first necessary to transfer a substantial quantity of state-owned companies to private hands. In doing so, the efficiency of specific enterprises was a minor topic. The difference between privatisation in Czechoslovakia and that in mature market economies, like Great Britain, was in the ratio between the quantity of property privatised and the volume of savings on the part of the population (Ježek, 2006). The difference was so gigantic, that, on its own, it turned out that the privatisation process in Czechoslovakia became entirely unique (Ježek, 2006). The ratio of state-owned property to savings of the population was of strategic significance in selecting the appropriate privatisation policy. It was unreasonable to adapt the privatisation to the rate of growth in savings on the part of the population since, considering the proportions of state-owned property, the process would take decades to complete. The capital shortage was tackled by a decision, according to which the strategic privatisation path would consist of free-of-charge transfers of state-owned property to domestic private entities (Ježek, 2006).

In April 1990, a decision was passed to develop a mass privatisation programme and in June of the same year, the new Czechoslovak Government, included privatisation in its agenda. It took another year to finalise the privatisation laws. Privatisation was divided into three main groups - restitutions, small-scale privatisation and large-scale privatisation (Švejnar, 1997).

The speed of privatisation was emphasised as one of the key points in the privatisation agenda and has continued to be a subject of many disputes even today. If Czechoslovakia, and, later on, the independent Czech Republic, adopted the same pace of privatisation as was the case of Poland, for example, the whole process would only be completed by 2008-2010 (Spicer et al., 2000). Two scenarios were considered in 1991: (i) a speedy process, which would have doubtlessly brought about a number of issues associated with the selling of the property rights to unproven candidates, and (ii) a slow approach to privatisation, which would have taken decades and would have in all likelihood been associated with a substantial rise in corruption. This was one of the reasons why the Czechoslovak Government ultimately decided to go with the former scenario of a speedy privatisation process.

The privatisation process took place amidst a very favourable social climate, yet at the same time faced complications related to a two-membered federation on the brink 
of disintegration (Ježek, 2006). Valuing the property to be privatised was another major problem in the Czech context. The carrying values of property held by the ineffective socialist enterprises, ${ }^{2}$ after years of isolation from global markets, constituted a primary information message both for designers of privatisation projects and for banks in their willingness to provide loans, despite the fact that in reality they were practically devoid of any explanatory power. It was effectively impossible to determine the real market value of the assets of the privatised enterprises in the economic environment. ${ }^{3}$

Restitution, as a term, was introduced in Czechoslovak law through Act No. 403/1990 Coll., whereby the property nationalised by the Communist Government after 1948 was returned to its original owners or their heirs. The restitution processes took place between 1990 and 1991 and included property at an overall book value of 200 billion CZK equivalent to 6.8 billion USD in 1991 (Mládek, 1994; Vychodil, 2005). In terms of the volumes involved, Czechoslovak restitutions are unparalleled in the region. The public played an indispensable role in the entire privatisation process. This fact is rather difficult to evaluate from the current perspective, yet it still needs to be noted that the Czechoslovak public at that time had been decimated by the authoritarian socialist state to such an extent that any delay on the part of the Government in transferring the property would have been received extremely negatively This fact was reflected in the Government political considerations. According to the public opinion, restoration of the market structure should have been associated with a renewal of the ownership rights of individuals who had once lost their property due to nationalisation. Property restitutions thus became the speediest method of privatisation (Ježek, 2006).

The first real stage of the privatisation was the so-called small-scale privatisation, launched in January 1991 and completed in 1993. The legal framework consisted of Acts No. 427/1990 Coll. and No. 500/1990 Coll. During the small-scale privatisation, smallsized economic units, such as shops, restaurants, etc., were sold in public auctions. In total, 22212 units were auctioned off at an overall value of 30.4 billion CZK (the amount was equivalent to 1 billion USD in 1991) - as calculated from the final selling prices (Žídek, 2004; Earle et al., 1994). It needs to be added that only domestic candidates could apply for the economic units offered. This stage of the privatisation was generally received positively, with the same process taking place in all neighbouring countries within the Eastern bloc (Žídek, 2004).

The small-scale privatisation along with restitutions and setting up of trades and small businesses helped to quickly reinstate a class of entrepreneurs and laid foundations for dynamic economic growth within the private sector, especially for small and medium enterprises.

Other state-owned productive assets, at an overall value of 350 billion CZK (equivalent to 11.9 billion USD given the exchange rate of 1991) were transferred to

\footnotetext{
${ }^{2}$ The values of state-owned and privatised assets given in this text are book values, since there is no way to obtain mutually consistent data giving a more "realistic" picture of the value of the assets in the early 1990 s.

${ }^{3}$ The role of the capital market during the transformation era was rather symbolic. There were two security markets in the Czech Republic - the Exchange and the RM-System, which evolved as a result of the voucher privatisation method applied. The RM-System made it possible for owners of shares to enter the security market directly.
} 
municipalities and communes and cooperatives at an overall book value of 150 billion CZK (5.1 billion USD), transformed to other forms of enterprises under private control (Mládek, 1994).

The next stage, referred to as large-scale privatisation, was launched in the spring of 1991 and mainly concerned large-sized industrial enterprises and banks (more than 3500 entities overall). The legal framework consisted of Acts No 92/1991 Coll. and No 171/1991 Coll. The privatised enterprises, at an amount of roughly 1200 billion CZK (40.7 billion USD in 1991) were either liquidated (with the assets of the liquidated companies generally sold under public auctions), or privatised during one of the two waves of largescale privatisation, or the privatisation was postponed and the property left under state control. The large-scale privatisation employed both standard methods (i.e. public auctions, public tenders and direct sales) and a peculiar amalgamation of the models proposed by Milton Friedman in the 1970s and formulated as part of a Polish academic discussion led during the 1980s, generally referred to as the Voucher Privatisation, which ultimately had a much bigger role to play in the programme of Czech large-scale privatisation than the standard methods (Kouba et al., 2005).

The overall book value of property entered in the large-scale privatisation process was 1200 billion CZK (in 1991 equivalent to 40.7 billion USD); of which 46\% was privatised by the voucher method while $25 \%$ was retained by the state and $15 \%$ was privatised by standard methods (Vychodil, 2005). Other property at a book value of 350 billion CZK (11.9 billion USD) was transferred to municipalities and communes.

The document central to the large-scale privatisation process was the so-called Privatisation Project. It contained a summary of information defining the privatised property once owned by the State; the forms of acquisition of such property, its price and parts that could not be used for entrepreneurial purposes; the method in which the privatised property was going to be transferred, including the settlement of any claims raised by eligible persons under restitution laws; the legal form of the companies set up; distribution of shares, i.e. the number of shares registered for the Voucher Privatisation; and the volume of state-owned property to be sold, including the price and terms of payment.

From an institutional point of view, the Ministry for National Property Administration and Privatisation and the National Property Fund of the Czech Republic were the two governing bodies in the large-scale privatisation process. The two institutions were responsible for transforming the ownership relations in respect of state-owned property. The National Property Fund of the Czech Republic (FNM ČR) was set up by the Czechoslovak Government to oversee the technical implementation of privatisation-related decisions and to undertake temporary administration of the shares held by the state designated for gradual privatisation. It was established on 24 May 1991, namely via Czech National Council (ČNR) Act No. 171/1991 Coll., concerning the scope of competence of Czech public authorities regarding the transfers of property to other entities, and on the National Property Fund of the Czech Republic. The main mission of the FNM ČR was to manage and privatise state-owned property in line with the approved Privatisation Project. The receipts generated by the FNM ČR as a result of the privatisation, which did not form part of the Czech state budget, could only be used for the purposes stipulated by the law, i.e. removing the damage caused by the more 
than 40-year-long state ownership, deleveraging the entities to be privatised, capital strengthening, transformation and stabilisation of the bank sector, strengthening the pension and healthcare insurance schemes, etc. A proportion of FNM ČR's funds were assigned to the state budget in the form of grants. In addition, the expenditures associated with the temporary administration of the privatised property had to be covered. The FNM ČR had no say in determining the manner in which state-owned property would be privatised. Its main task was to implement privatisation projects based on privatisation decisions issued by the Ministry of Finance of the Czech Republic or resolutions of the Czech Government. ${ }^{4}$

Large-scale privatisation was carried out through a combination of several methods. Small enterprises were auctioned off or sold under tenders ${ }^{5}$, while mediumsized enterprises were sold under tenders or direct sales. Large-sized companies were transformed into joint-stock companies, with their shares either sold under voucher privatisation, sold for cash, or transferred to municipalities at no charge. ${ }^{6}$ It was in no way exceptional for several sales methods to be combined (Kočenda \& Lízal, 2003).

The undoubtedly most dominant methods of the overall privatisation process were voucher privatisation (Katolay \& Hunya, 2000) and direct sales (Ježek, 2006). These two privatisation patterns accounted for property rights transfer worth up to 570 billion CZK (equivalent to 19.3 billion USD in 1991), i.e. accounting for $73.1 \%$ overall. Therefore, the next chapters and the following analysis will deal, in detail, with these two methods only.

\section{(a) Voucher Privatisation}

Voucher privatisation was a privatisation method, under which citizens were provided with an opportunity to purchase voucher books, at a low cost, with a certain number of vouchers (coupons), which they could redeem for interests in any state-owned companies released for the voucher privatisation by public authorities.

The main goal of voucher privatisation was not to assure a sufficient capital infusion, but rather to provide an equitable distribution of property among the population (Ježek, 2006). The voucher privatisation became a dominant method of the large-scale privatisation process and, at once, a guarantee that the essential requirement stipulated for the privatisation process, i.e. its speed and mass character, would be met in order for a gigantic amount of state property to be transformed within an acceptable period of time.

The general concept of mass privatisation was not a Czechoslovak invention. It was first conceived in Poland in 1988 (Earle et al., 1994). The idea of distributing vouchers and providing equal population participation was developed by the market-oriented advisors of the Solidarity Movement in Gdansk, Poland, in mid-1988. The intention was to use vouchers as replacement of the insufficient capital supply. As a specific type of

\footnotetext{
${ }^{4}$ The Fund was dissolved by Parliament Resolution in 2005, through Act No. 178/2005 Coll., concerning the dissolution of the National Property Fund of the Czech Republic and concerning the competence of the Ministry of Finance under the privatisation of property owned by the Czech Republic. At the end of 2005, the Ministry of Finance assumed the role of the Fund.

${ }^{5}$ Public tender procedure, invitation.

${ }^{6}$ As an example, the property transferred to municipalities mostly involved unused land situated within their territories.
} 
investment currency, the vouchers were distributed among the population and traded for stocks of the privatised companies. The voucher privatisation method was later creatively embraced by a number of European transition countries including former Czechoslovakia.

The full set of fundamental processes and financial parameters of voucher privatisation was listed in the Federal Czechoslovak Large-Scale Privatisation Act. On 5 September 1991, Government Decree No 383/1991 Coll. on the issue and use of investment vouchers was issued. Prior to registering state-owned enterprises in the privatisation process, it was necessary to convert their legal form to that of joint-stock companies as per Act No. 4/1990 Coll. According to the initial plans, 3\% of the shares were subsequently transferred to the so-called Restitution Fund, while the remaining $97 \%$ were privatised using the voucher method.

Two main variables were established: a specific preset quantity of assets to be privatised in one go, and a defined time period of the process, from its commencement to its ultimate end,. The process eventually had to be split into two privatisation waves. In June 1991, the Government published a list of state-owned enterprises (state-owned joint-stock companies), identifying those that would be privatised during the first and second wave of the privatisation, those that would not be privatised within the next five years and those earmarked for liquidation. Later, a list of enterprises earmarked for voucher privatisation was compiled (Švejnar, 1997).

The demand side of the voucher privatisation consisted of so-called voucher books distributed to the population starting from late 1991 (first wave), and autumn 1993 (second wave). Every Czechoslovak (and Czech, for the second wave) citizen aged 18 and more, with a permanent residence in the country, could apply for one voucher book at a nominal price of 1000 CZK (33.9 USD). Each voucher with a nominal value of 1,000 points was divided into ten sections, 100 points a section. The citizens could then redeem those points for the shares offered under either wave. Each participant in the voucher privatisation could assign the total of their points, or any proportion thereof, to one or more investment funds. During the rest of the privatisation wave, these funds had rights similar to those of participants of the voucher privatisation (Švejnar, 1997).

The first wave of the voucher privatisation was launched in November 1991 and was officially closed on 31 January 1993. During this period, interests in the total of 1491 joint-stock companies were privatised (including 988 in the Czech Republic and 503 in Slovakia) at an overall value of 299.39 billion CZK (10.2 billion USD), of which 212.49 billion CZK in the Czech Republic. The selected privatisation method turned out to be effective in terms of technical implementation. During very few rounds, which took seven months overall, $93.8 \%$ of the shares registered under the first wave were sold (Žídek, 2006).

Started in 1991, the voucher privatisation was designed to fit the conditions of a single country - the Czechoslovak Federal Republic (ČSFR) and its first wave was indeed launched in a single country. Yet, it was concluded on 31 January 1993, i.e. a month after the establishment of two independent countries (the Czech Republic and the Slovak Republic). In total, 8541000 citizens registered for the first privatisation wave, of which 5948500 in the Czech Republic and 2592500 in Slovakia (Ježek, 2006). 
The second wave was launched following the split of the Federation ${ }^{7}$ and only applied to the newly established Czech Republic. The second wave was regarded as a natural completion of the Government Transformation Programme and there were no opponents to the process, not even among the opposition (Tríska, 2002). During the second wave (Table 1), concerns in 861 enterprises were privatised at an overall value of 155 billion CZK (5.3 billion USD according to the exchange rate in 1993). Of the overall number of shares offered, $96.3 \%$ were sold.

Table 1. Two waves of voucher privatisation in the Czech Republic

\begin{tabular}{|l|c|c|}
\hline \multicolumn{1}{|c|}{ Criteria } & Wave 1 & Wave 2 \\
\hline Number of state enterprises entering the voucher scheme & 988 & 861 \\
\hline Book value of shares allocated for vouchers in particular wave (in billion CZK) & 212.5 & 155.0 \\
\hline Participating citizens (in millions) & 5.98 & 6.16 \\
\hline Average accounting value of assets per participating citizen (in CZK) & 35535 & 21160 \\
\hline$\%$ of voucher points with IPFs & 72.2 & 63.5 \\
\hline
\end{tabular}

Source: Kočenda \& Valachy (2001, p. 8).

In total, 6161000 citizens registered for the second wave. Major interest was also recorded on the part of investment companies, with 349 of them registering for the second wave, most of which had already participated in the first wave. During the second wave, once again, most voucher holders preferred the indirect method of investment, entrusting their points to investment funds. The percentage of these investors, dropped compared to the first wage, to $64 \%$ compared to $72 \%$, which was the figure during the first wave (Ježek, 2006).

Not only did the voucher privatisation place no requirements on the state budget, it even brought merits in this area. The net receipts booked by the FNM amounted to CZK 8.6 billion (USD 0.3 billion). Most income was generated by sales of voucher tokens and voucher books, while the main expenditures concerned purchases of IT, operation of the entire system, production of voucher books and tokens and information services, etc. (Ježek, 2006).

Investment Privatisation Funds (IPF) had an active role to play in the application of the voucher privatisation method. As a result of their massive participation in the privatisation, IPFs belong to major shareholders of Czech enterprises privatised via the voucher method. The funds amounted to the most popular investment pattern for the population redeeming their vouchers under the voucher privatisation scheme. The first privatisation wave was initially off to a slow start, but thanks to an advertising campaign several IPFs soon registered a multiple-fold growth in demand. IPFs promised a $1000 \%$ return on investment within one year. They drew upon the artificially set amount of 1000 CZK (33.9 USD) per voucher book and the estimated book value of the shares that could be redeemed per book on average, i.e. 35000 CZK (1187 USD). As a result, a promise of

\footnotetext{
${ }^{7}$ The split of the ČSFR was addressed by Constitutional means, namely Constitutional Act No. 542/1992 Coll., concerning the expiry of the ČSFR, adopted by the Federal Assembly on 25 November 1992, with a consensus reached on all disputes regarding the state boundaries and division of the federal property.
} 
10000 CZK (339 USD) per voucher book under the advertising campaign amounted to little risk on the part of IPFs (Kočenda \& Lízal, 2003).

During both voucher privatisation waves, Investment Privatisation Funds and holding funds accumulated approx. $60 \%$ of the overall property offered. However, of the overall property accumulated by the funds at its market value in 1996, property worth 49.6 billion CZK (1.7 billion USD) was misappropriated - the figure represents a qualified estimate of the Head of Security Commission's Collective Investment Department. The largest part, amounting to 40 billion CZK (1.4 billion USD), was misappropriated from the funds in the context of their transformation into holdings, while the rest, amounting to 9.6 billion CZK ( 0.3 billion USD), directly disappeared from the non-transformed funds (Ježek, 2006).

\section{(b) Direct Sales}

Both privatisation waves combined capital and non-capital privatisation methods. Voucher privatisation was the most widespread free-of-charge non-capital method. Capital privatisation methods included public auctions, direct property sales and direct sales of shares and public tenders. The comparison of specific sales techniques imply that the largest capital inflows registered by the FNM resulted from direct sales and amounted to 52 billion CZK (1.8 billion USD), public tenders to 21 billion CZK ( 0.7 billion USD) and public auctions to 7 billion CZK (billion USD 0.2) (Ježek, 2006).

For direct sales of property to predetermined acquirers, the FNM would initially draft and enter into a purchase agreement; for sales of property under a public auction or public tender, the FNM was in charge of the preparation and execution of the auctions and tenders. During privatisation by investing state-owned property in joint-stock companies and subsequently selling the resultant shares, the FNM initially acted as the founder of the companies, then as the main shareholder and eventually as the seller or transferor of the shares (Ježek, 2006).

But the intention of Czech entrepreneurs and foreign proponents of privatisation projects under the large-privatisation process, was to win an opportunity to acquire property rights, not just shares. As long as shares were only available, then the intention was to get hold of the controlling interest. Therefore, direct sales became the second most important privatisation method (Ježek, 2006).

It was at this stage of the privatisation process that the candidates eligible to secure ample bank financing for their property acquisitions, entered the process. In many cases, the investors were the management of existing companies or groups of people in possession of sound knowledge of the companies concerned and capable of paying the required amounts. It needs to be noted, however, that during the 1990s, sufficient capital funds had not yet been accumulated in the hands of specific Czech investors, who, in an effort to acquire the resources required to invest in such companies under the direct-sale scheme, used methods that may be regarded as largely unconventional from the contemporary point of view. The mix of internal and external resources, including those of the company, was sometimes a way to make the privatisation process possible. At the same time, the general expectation was that the costs of privatisation for the companies assigned under the control of their respective management would be borne by the companies themselves. In many cases, this was the only way to allow for the transaction to be completed (Ježek, 2006). 
The government actors at that time were clearly aware that such procedures were being pursued, yet during the transition, they could hardly be regarded as non-standard. They must be evaluated within the context of the era, among other things, with regard to public opinion (and, by inference, the action of the political elites), which, as an example, did not always favour sales to foreign investors. In addition, only Czech investors capitalising on both their knowledge of the field and political lobbying, were willing to invest in very specific enterprises or companies dealing in strategic commodities, e.g. in the energy sector. The pressure to speed up the sales of property and to accelerate the initial stages of the restructuring process for most enterprises was a priority task for most governments during the 1990s, since the governments themselves possessed neither the funds to restructure the companies, nor the required human resources for their managements (Ježek, 2006).

The sales of companies were further accelerated by the threat of a growing corruption rate recorded in administration of state-owned companies. Foreign groups and medium-sized international investors gradually grew to become dominant investors under the direct sales scheme. The share of foreign operators in the receipts of the FNM generated by the sales of shares finally accounted for over three quarters, $78.4 \%$ (Ježek, 2006).

The privatisation resulted in a massive inflow of foreign capital (Uhlenbruck \& De Castro, 2000), especially during its early stages. Since its establishment in 1991, the FNM assigned to foreign investors over 60 large-sized companies, with Škoda Mladá Boleslav as the largest of them (Škoda Auto a.s.). At that time, the Czech Government was confronted with the indignation of a major part of the public, which was opposed to what was referred to as the "selling out" of national property to foreigners (Ježek, 2006). During the first years, the influx of foreign capital to the Czech Republic did not have to be induced by any investment incentives, or even any underlying conceptual considerations of the Federal Ministry of Finance on the method of integrating foreign investors into the economy. Therefore, even this part of the project, similarly to the direct sales to domestic investors, was non-standard to a certain extent, yet indispensable from the viewpoint of speedy privatisation. The manner, in which these transactions were negotiated and structured was coordinated by a team of advisors and investment bankers financed by the American governmental US AID. The objective was to guarantee from the Czech Republic investors with long-term plans, building an exportoriented companies and sustaining jobs.

Table 2. Property under large-scale privatisation in the Czech Republic in the years 1991-2005

\begin{tabular}{|l|c|c|}
\hline \multicolumn{1}{|c|}{ Type of privatisation } & Book value CZK/USD & $\%$ \\
\hline Voucher privatisation & 333 billion/11.3 billion & 42.7 \\
\hline Direct sales & 237 billion/8.0 billion & 30.4 \\
\hline Free-of-charge transfer to municipalities and communes & 121 billion/4.1 billion & 15.5 \\
\hline Free-of-charge transfer to reserve funds of joint-stock companies & 64 billion/2.2 billion & 8.2 \\
\hline Free-of-charge restitution transfers & 25 billion/0.84 billion & 3.2 \\
\hline Total & 780 billion/26.4 billion & 100 \\
\hline
\end{tabular}

Source: own elaboration based on National Property Fund (2005). 
For the purposes of the present analysis, we have considered 2005 as the official final year of the privatisation process (among other things, the year of dissolution of the FNM ČR). The property registered under the large-scale privatisation was appraised at its book value and gradually privatised using various methods as described in the preceding chapters. Proportional representation of the methods is shown in Table 2.

\section{Analysis of the Results of Privatisation in the Czech Republic on the Sample of Selected Czech Privatised Companies}

Due to a lack of analyses devoted specifically to methods of privatisation and their benefits, we decided to explore the effects and parameters of a group of selected enterprises privatised under the large-scale privatisation. The enterprises were picked out of a list of units privatised by the FNM ČR. Out of approximately 3500 large-scale privatized units, we picked 60 enterprises from the industrial sector. The main criterion for inclusion and selection of the enterprises to be examined was staff count exceeding 250 at the time of the privatisation.

60 selected major enterprises privatised between 1991 and 2005 were divided into three groups under consideration, depending on the privatisation method. The groups were created with an account taken of the importance of the specific methods, namely as follows:

- Group (1) consisted of enterprises privatised via direct sales to foreign investors $(n=20)$;

- Group (2) consisted of enterprises privatised under voucher privatisation ( $n=20)$;

- Group (3) consisted of enterprises privatised via direct sales to domestic investors $(n=20)$.

These 60 privatised enterprises, which, at the onset of the process, were expected to "start up the economy", were assessed for the following factors:

a) the overall public income tax revenue for all the units within the group, starting from the end of privatisation and during the entire existence of the privatised business units or their successors;

b) average annual number of direct jobs created by the group of enterprises under consideration, namely starting from the end of privatisation and during the entire existence of the privatised business units or their successors;

c) value added per employee generated on an annual basis.

The principal starting point for the actual comparative analysis, therefore, did not consist in comparing the expenditures of the large-scale privatisation to the receipts from the sales of privatised property. Since, after deduction of the expenditures, the FNM ČR reported a final balance, as at 31 December 2005, in respect of the funds under the large-scale privatisation process of 59480224578 CZK (2483 billion USD). The positive balance of total receipts and expenditures from the start of existence of the FNM ČR reported in the 2005 FNM Annual Report (Table 3) means that the expenditures associated with large-scale privatisation were fully covered by the receipts from the property sold. In this, we draw upon the consideration that the expenditures reported by the FNM from the onset of the privatisation process in 1991 until 2005 represent overall expenditures on the direct privatisation of all units privatised during the above period, 
while the receipts of the FNM from the onset of the privatisation process in 1991 until the end of 2005 constitute the overall receipts form the sales of all units privatised during the aforementioned period.

Table 3. Overview of cash receipts and expenditures from the onset of existence of the FNM ČR (1991-2005)

\begin{tabular}{|l|r|}
\hline \multicolumn{1}{|c|}{ Types of receipts and expenditures } & \multicolumn{1}{c|}{ Value in CZK (in USD) } \\
\hline Total receipts, including: & 633376561093 (26.44 billion) \\
\hline Receipts from sales of property and shares & 533721750100 (22 billion) \\
\hline Receipts from loans & 36410267000 (1.52 billion) \\
\hline Public receipts & 63244543993 (2.64 billion) \\
\hline Total receipts & 633376561093 (26.44 billion) \\
\hline Total expenditures & 573896336515 (23.96 billion) \\
\hline Receipts/Expenditures Balance & 59480224578 (2.483 billion) \\
\hline
\end{tabular}

Source: own elaboration based on National Property Fund (2005).

Figure 2 shows overall income tax revenues for all enterprises under consideration per specific groups, starting from the end of privatisation and during the entire existence of the privatised enterprises. According to the studies completed, the group of enterprises privatised under direct sales to foreign investors, i.e. Group 1 (hereinafter referred to as Group 1) could be expected to report the best results in absolute figures, which their comparison to the results reported by Group 2 - enterprises privatised under voucher privatisation (hereinafter referred to as Group 2) and Group 3 eventually confirmed. Group 3 - enterprises privatised by direct sales to domestic investors (hereinafter referred to as Group 3) reported a lower share in the tax revenues. Group 1 and Group 3 contributed 40.4 billion CZK (2.08 billion USD) and 9.5 billion CZK (0.49 billion USD), respectively, to public tax revenues.

Surprisingly, the enterprises privatised under voucher privatisation are evaluated negatively in most available studies, reporting poor results even when compared to stated-owned companies, particularly in the area of efficiency and profitability. From the viewpoint of the present analysis, however, these figures hardly represent factors as important as the overall volume of tax revenues and creation of jobs. Group 2 contributed 18.4 billion CZK (0.95 billion USD) to the public tax revenues (Figure 2).

Figures 3 shows comparison of average annual number of jobs created by the privatized companies. Enterprises of Group 2 had annually, on average, 21778 employees, from the onset of the privatisation process until now, which puts the companies into the role of major employers in the Czech Republic. However, companies from Group 1 are reported clearly the highest annual numbers of direct jobs, namely 40 367, almost twice more compared to those in Group 2. Companies classified to Group 3 created on 14454 jobs annually on average.

The Added Value per employee is also the key indicator, both in terms of efficiency and in terms of comparability of all enterprises, regardless of their size. In this area, once again, the group of companies sold directly to foreign investors reports the highest 


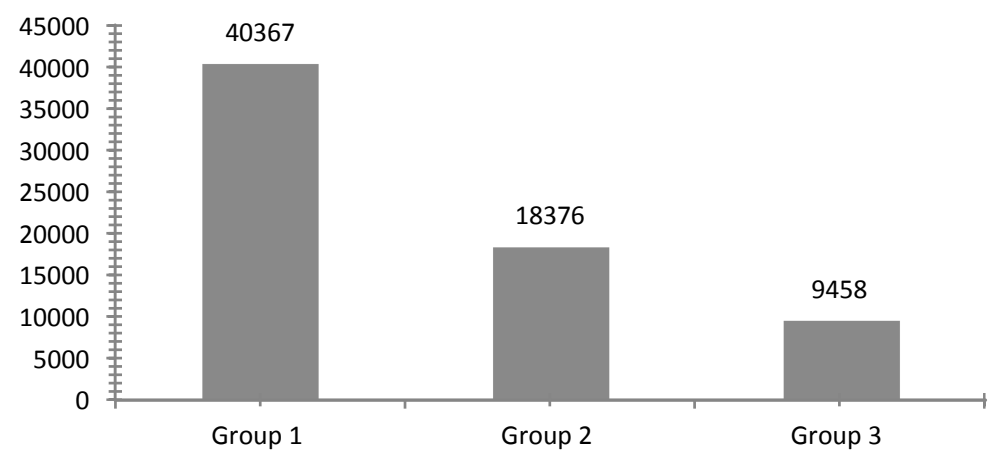

Figure 2. Tax revenues during the entire existence of the companies (starting from the end of privatisation) in millions of CZK (CZK 45 billion = USD 2.3 billion)

Source: own elaboration based on Specific Research of University of Finance and Administration (2013).

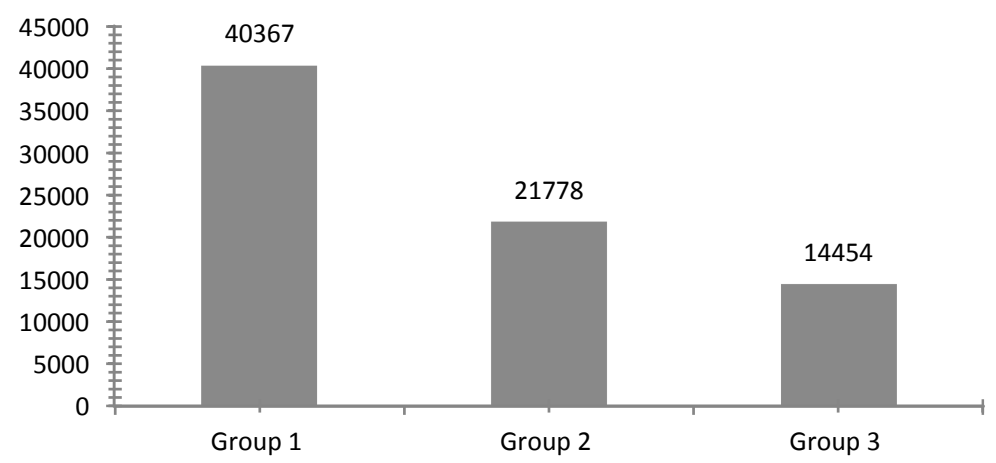

Figure 3. Comparison of average annual number of jobs created by the investigated companies (starting from the end of privatisation during the entire existence of the companies) Source: own elaboration based on Specific Research of University of Finance and Administration (2013).

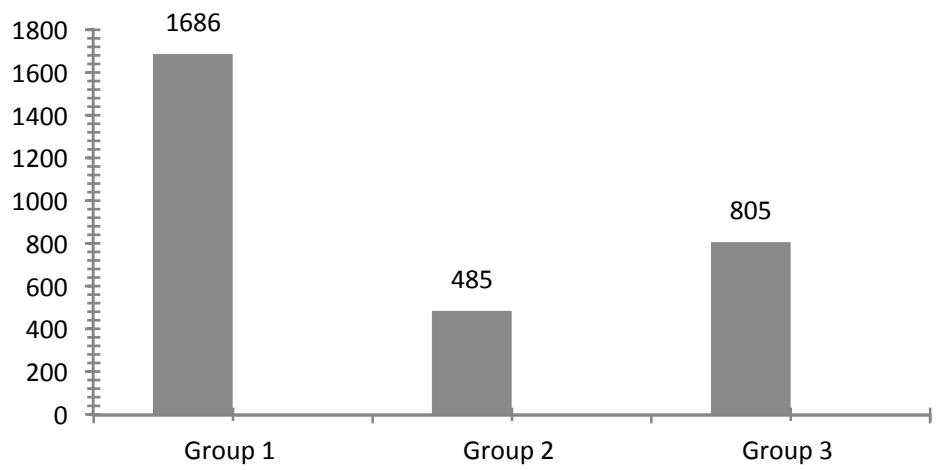

Figure 4. Comparison of Added Value per employee (starting from the end of privatisation during the entire existence of the companies) in thousands of CZK (CZK 1,800,000 = USD 92,500)

Source: own elaboration based on Specific Research of University of Finance and Administration (2013). 
values per employee, namely 1686000 CZK (86 700 USD). On the contrary, the companies privatised under voucher privatisation report the lower figures, namely 485000 CZK (24 900 USD). In contrast, the group of enterprises sold directly to domestic investors reports very intriguing Value Added. The comparison of the three groups is given in Figure 4.

\section{CONCLUSIONS}

The Czechoslovak and later on Czech privatisation was a unique, historically unrepeatable operation. Undoubtedly, the approaches employed under the whole process were unconventional regarding the tackling of the need to privatise most of state property within the shortest possible amount of time, and, what is even more important, without accumulated capital among the population. The crucial criterion in the privatisation was the time factor, and therefore a scenario which favours a speedy transfer to specific owners was opted for. The overall property transfer strategy had speed of the process as its fundamental criterion and involved selecting such owners that would have, if not demonstrable, then at least the minimum capacity required to complete the subsequent restructuring process and to set up such procedures that would secure continued operation of the enterprises.

The obtained results (values for three selected economic indicators) confirm that the best results in all of the three areas under consideration were reported by the companies sold directly to foreign investors (Group 1). Compared to the companies sold directly (Group 1 \& Group 3), the enterprises that were submitted to the voucher privatisation (Group 2) were capable of creating more jobs, while the companies sold directly to domestic owners (Group 3) exhibited a higher value added per employee compared to those privatised under the voucher privatisation, i.e. they were managed more efficiently, which created the required preconditions to their sound lifecycles and further operation.

The expenditures associated with the large-scale privatisation were covered by the receipts from the sales of property rights. Based on the conducted analyses, it may be inferred that despite the fact that the best results have been reported by the companies sold directly to foreign investors, voucher privatisation and direct sales to specific domestic investors can also be regarded as acceptable overall. The general and unique climate of the 1990s, which was characterised by high expectations of the public as regards the fastest possible transfer of state-owned property to private investors made it possible for a large segment of the population to acquire property rights at relative ease. In its very nature, the voucher privatisation literally encouraged both the citizens and investment funds to take part in what essentially amounted to handing out of public property. Considering that neither the population nor investment funds or managers of the companies to be privatised did or could possess substantial capital, the process was generally received as acceptable and therefore cannot be compared to the sales of property in countries with advanced economies.

The results of empirical analysis presented in the article have demonstrated that a quick sale to foreign or domestic owners has been the most beneficial for Czech economic environment as far as the long-term effectiveness of enterprises is concerned, 
but the sale via vouchers to a large number of investors was also a benefit for the stability of the economic environment, in view of tax revenues in later years.

Taking into consideration the above discussed results, it is highly recommend for further research to be pursued, especially comparing other economic variables, One suggestion is export volumes and values, as they relate to export turnover and to creation of value added of exported products. A demographic study focused on determining the effects of privatised companies on the sociological environment in regions of the Czech Republic based on individual privatisation methods is another possible research avenue. More comparative studies focused on comparison of privatised methods and companies in Slovakia, Poland and Hungary with those in the Czech Republic are still needed. Furthermore, scientific studies that will evaluate the proportion of survivors and bankrupt privatized enterprises will bring us closer to evaluating the Czech privatisation on numerous levels.

\section{REFERENCES}

Annual Report (2005). National Property Fund. Ministry of Finance, Prague.

Earle, J. S., Frydman, R., Rapaczynski, A., \& Turkewitz, J. (1994). Small Privatization: The Transformation of Retail Trade and Consumer Services in the Czech Republic, Hungary and Poland. Budapest: CEU Press.

Ježek, T. (2006). Privatisation of the Czech Economy: Its Roots, Methods and Results. Prague: Oeconomica.

Katolay, \& K., Hunya,G. (2000). Privatization and FDI in Central and Eastern Europe. Transnational Corporations, 9(1): 39-66.

Klaus, V., Dlouhý, V., Dyba, K., Tříska, D., Čalfa, D., Kočárník, I., Fürstová, J., Šíp. E., Wigl, J., Loužek, M., \& Janáčková, S. (2006). Fifteen Years from the Reinstitution of Capitalism in Our Country. Prague: CEP Collection.

Kočenda, E., \& Valachy, J. (2001). Secondary privatization in the Czech Republic: Changes in Ownership and Enterprise Performance in Voucher-Privatized Firms. Case Reports No. 45. Warsaw: Centre for Social and Economic Research CASE.

Kočenda, E., \& Lízal, L. (2003). Czech Companies in Czech Transformation 1990-2000. Prague: Academia.

Kouba, K., Vychodil, O., \& Roberts, J. (2005). Privatisation without Capital. Prague: Karolinum.

McAllister, I., \& Studlar, D.T. (1989). Popular versus Elite Views of Privatization: The Case of Britain. Journal of Public Policy, 9(2): 157-178.

Mládek, J. (1994). Voucher Privatization in the Czech Republic and Slovakia (pp. 39-47). In: Mass Privatization - An Initial Assessment. Paris: OECD - Center for Co-operation with the Economies in Transition.

Pohl, G., Anderson, R.E., Claessens, S., Djankov, S. (1997). Privatization and Restructuring in Central and Eastern Europe. World Bank Technical Paper No. 368 (series: Finance, Private Sector, and Infrastructure Network), 5-10.

Specific Research of University of Finance and Administration (2013). Comparison of key performance factors of Czech large and medium-sized companies. Prague: Faculty of economics studies. 
Spicer, A., McDermott G. A., \& Kogut, B. (2000). Entrepreneurship and Privatization in Central Europe: The Tenuous Balance between Destruction and Creation. The Academy of Management Review, 25(3): 630-649.

Švejnar, J. (1997). The Czech Republic and the Economic Transformation in Central and Eastern Europe. Prague: Academia.

Tříska, D. (2002). Background, Aims and Principles underlying the Voucher Privatisation. Prague: CEP Collection.

Uhlenbruck, K., \& De Castro, J.O. (2000). Foreign Acquisitions in Central and Eastern Europe: Outcomes of Privatization in Transitional Economies. Academy of Management Journal, 43(3): 381-402.

Vychodil, O. (2005). Impacts of Post-Privatisation Concentration of Property on the Efficiency of Czech Companies. In K.Kouba \& O.Vychodil (Eds.), Privatisation without Capital - Increased Transaction Expenditures of Czech Transformation. Prague: Karolinum.

Žídek, L. (2004). The Czech Economy in the 1990s. Brno: Masaryk Univerisity in Brno, Faculty of Economics and Administration.

Žídek, L. (2006). Transformation of the Czech Economy: 1989-2004. Prague: C.H. Beck. 


\section{Authors}

The contribution of the authors is as follows:

Karel Havlíček - 40\%, Ivana Turková - 30\%, Gabriela Dlasková - 30\%.

\section{Karel Havlíček}

Karel Havlíček is Associate Professor at the Department of Business Administration and Dean of the Faculty of Economic Studies, University of Finance and Administration. He is also Chairman of the Association of Small and Medium-Sized Enterprises of the Czech Republic, a delegate of the European Economic and Social Committee within the EU and member of a number of governmental and European institutions in the area of entrepreneurial environment. $\mathrm{He}$ is author of over 100 publications and was participant of a number of Czech and international conferences.

\section{Ivana Turková}

Ivana Turková is a PhD student in Finance and Assistant Professor at the Business Administration Department, University of Finance and Administration.

\section{Gabriela Dlasková}

Gabriela Dlasková is a PhD student in Finance and Assistant Professor at the Business Administration Department, University of Finance and Administration.

\section{Correspondence to:}

Assoc. Prof. Karel Havlíček, PhD, MBA

Faculty of Economic Studies

University of Finance and Administration

Estonská 500, 101 00, CZ - Prague 10, Czech Republic

karel.havlicek@vsfs.cz

\section{Copyright and License}

This article is published under the terms of the Creative Commons Attribution - NonCommercial - NoDerivs (CC BY-NC-ND 3.0) License

http://creativecommons.org/licenses/by-nc-nd/3.0/

Published by the Centre for Strategic and International Entrepreneurship - Krakow, Poland 